JOURNAL OF

French and Francophone Philosophy
REVUE DE LA

philosophie française et de langue française

\title{
The Intuitive Recommencement of Metaphysics
}

Camille Riquier (translated by Erik Beranek)

Journal of French and Francophone Philosophy - Revue de la philosophie française et de langue française, Vol XXIV, No 2 (2016) 62-83.

\author{
Vol XXIV, No 2 (2016) \\ ISSN 1936-6280 (print) \\ ISSN 2155-1162 (online) \\ DOI $10.5195 /$ jffp. 2016.771 \\ www.jffp.org
}

\section{(c) EY-NC-ND}

This work is licensed under a Creative Commons Attribution-Noncommercial-No Derivative Works 3.0 United States License.

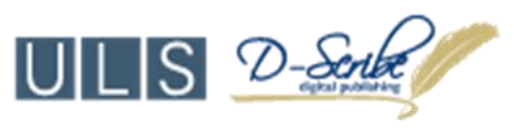

This journal is operated by the University Library System of the University of Pittsburgh as part of its D-Scribe Digital Publishing Program, and is co-sponsored by the University of Pittsburgh Press 


\title{
The Intuitive Recommencement of Metaphysics
}

\section{Bergson's Kantianism}

\author{
Camille Riquier (translated by Erik Beranek) \\ Catholic University of Paris
}

In retaining the name of metaphysics, in reinstating its prerogatives, is Bergson a pre-critical philosopher, who has lost his way in our modernity? Is it not imprudent of him to stick his neck out-here, where the Kantian tribunal regularly lets fall the blade of its guillotine-when he declares possible what the Critique of Pure Reason asserted to be impossible? Or is he a resolutely modern philosopher, who takes care at each instance to remove the objections that Kant could have inflicted upon him, including even the illusions upon which his Critique rested? The question will have to be formulated differently if we are to shed light on the relationship that Bergson maintains with Kant, for the relationship is too complex for us to be able to resolve it with such a clean cut. If Bergson passed through his studies without encountering any German influence, if he even began to write heedless of the Kantian interdictions that weighed upon his project, the obstacle that Kant set down in his path had to capture his attention eventually, for he was reminded of it constantly. Even when already well upon his way, he was assured that he was really getting nowhere-such was the extent to which his ignorance of the critical turn must have served in place of a devastating objection to his metaphysics. The fact remains that the "break" with Kantianism, which he "only glimpsed"1 when writing Time and Free Will, was given greater and greater emphasis. Discreetly with Matter and Memory, then openly in his "Introduction to Metaphysics," Bergson wanted to remove the obstacle, to confront it. Since that was the atmosphere of his time, that was also the language he had to borrow if he wanted to be understood: the "Introduction to Metaphysics" (1903), as Bergson recalls, "was written at a time when Kant's criticism and his successors' dogmatism were more or less generally accepted, if not as its conclusion, at least as the starting point of philosophical speculation." 2 And thus, since the end of metaphysics had been proclaimed 
("conclusion"), Bergson had to introduce us to metaphysics anew, after Kant had given its critique ("starting point").

We must, however, be clear. Was metaphysics only interrupted? Strictly speaking, it is or it is not, and the paradox would be that Bergson would have had to wait for his confrontation with Kant before he could begin doing metaphysics. He would have had to wait for Creative Evolution to clear up the illusions of nothingness and of disorder that encircle our intelligence and convince it that the real is distant or inaccessible. But in reality, these illusions are always already cleared up for an intelligence that intuition has long since "shaken from its [dogmatic] slumber," 3 as was the case for Bergson from the time of his first book; only later are they recognized for what they are. Kantian critique, which rests entirely upon them, can therefore be ignored for quite some time. For it neither hinders nor postpones the forward march of a thought that has already inhaled the air that bears the thing itself, as it is "in itself" - only a thought encumbered with ideas of its own making, which it carries along "as impedimenta" 4 would be so impeded. That is why critical questions only bother the one who poses them ("what can I know?," what must I do?," what am I permitted to hope for?"). Human thought "can equally well ignore Kantian philosophy and the 'theories of knowledge' which derive from it,"5 and go straight to the essential questions that the Kantian moratorium had put to an end, making it such that they could no longer arise for anyone: "Whence are we? What are we? Whither tend we? These are the vital questions, which immediately present themselves when we give ourselves up to philosophical reflexion without regard to philosophical systems." 6 These are questions, Pascalian in their formulation, that Bergson was able to reinvest only after having saved them from the state of dialectical upheaval Kant had left them in - unanswered, if not abandoned to oblivion when he bound them to rational psychology. ${ }^{7}$ In other words, the only means Bergson found for responding to the question "what is man?" was to begin by posing it, naively, without passing, like Kant, through the preliminary study of the mechanism of our thought. "[T]he metaphysician does not thus sacrifice the use of the mind for the criticism of mind, the end for the means, the prey for the shadow," 8 and if Bergson did critique Kant at times, it was to the extent that the Critique prevented him or others from moving forward. Moreover, the critique he addressed to him might have fallen along with the obstacle had Bergson not proposed, more extensively, to critique the natural mechanism of our intelligence and its aforementioned illusions, which have in fact been present since Zeno, and which Kant simply has the merit of having systematized. Does nothingness precede being, and disorder, order? "The whole object of the Critique of Pure Reason," Bergson writes, "is, in fact, to explain how a particular order is superadded to supposedly incoherent materials." 9 Kant condenses illusions that existed before him. In this sense, Bergson is neither post-Kantian nor pre-critical. Nor, for that matter, was he ever "Kant's adversary." 10 


\section{Pre- or Post-}

(i) Was Bergson post-Kantian? If the Critique is the trial by fire to which Bergson agreed to submit his metaphysics, so that it might die there and be reborn like a phoenix, this risk does not suffice to make Bergson a postKantian in the strict sense. Paraphrasing a passage from "Philosophical Intuition," we might maintain that Bergson would have been the same without Kant, although he would "doubtless have written something other than what he wrote."11 Kant is for him what, in his eyes, Descartes was for Spinoza, namely, the language that was spoken in his time and the doctrine one had to don in order to communicate therein. More than any other text, the "Introduction to Metaphysics" retains his trace. But the intuitive ground of the Bergsonian doctrine really goes back, beyond Kant, to Descartes himself: an active cogito, immersed in concrete duration.

(ii) Was Bergson therefore pre-critical? To an even lesser extent is Bergson pre-critical, and though Cartesian, he took note of obstacles that could block his way, surmounted them as he met them, and wanted, in fact, to lift metaphysics up [relever] after Kant had felled it. And he could not remove those obstacles without attacking the illusions that were found clinging to their roots, on account of which Kant still shared more with the metaphysics of the ancients, against which he fought.

We must take a step to the side, then, if we want to grasp the true relationship between Bergson and Kant, which is too subtle to be confined to the alternative with which we began - and which is sufficiently explicit and even surprising when one thinks of the declarations made in the final chapter of Creative Evolution, where, instead of confirming the clunky opposition one might have naively expected, Bergson declares himself to be Kantian. After Descartes, before Spencer, Kant is another "missing precursor of Bergson." 12 In Bergson's eyes, Kant, like Descartes, contains two possible paths for philosophy, which reflect the two fundamental tendencies that are mixed together in the élan vital and continued in humankind: intuition and intelligence. Thus, Bergson shifts the lines and breaks with Kant from the inside of his philosophy, which he divides into two Kantianisms: the one, which he rejects as ancient, and the other, which he appropriates. It is not, however, a question of drawing out a latent Bergsonism in Kant, as Alain Panero thought, but rather of restoring the Kantianism that is completed in Bergson - a Kantianism that embarked down a path that Kant himself, who held himself back from following it in order to dispense with all "intellectual" intuition, had only sketched. The "Introduction to Metaphysics," then, is not written simply to settle the score with Kant, as if the latter represented a levee holding back "the surge of metaphysics"13 and would ultimately have to give way before the fullness of the sea. In it, Bergson indicates: first and foremost, that the metaphysics that is already underway, and which he intends to develop, 
no longer has anything in common with the metaphysics practiced before Kant; that he is even the first to lift it up [relever] after the blow Kant had dealt it; and that he proposes to modify its status sufficiently for it to be able to withstand all critiques, for it alone to succeed in moving beyond them, unexpectedly using the Critique toward this end. Thus, if Bergson is to be believed, an intuitive metaphysics, which installs itself in pure duration, is neither below nor beyond Kantian critique, but can pass through it, can traverse it in its entirety, since it proposes to surpass it, to prolong it following the path that Kant himself had cleared in order to fulfill its suppressed virtualities. Indeed, on many points Bergson follows the outlines of the first Critique, the Critique of Pure Reason, the only one he took into consideration. We are not yet in the period when commentators will look to the third Critique for the means of reconciling the first two. Charles Péguy recalled that at that time "the Kantians were divided naturally in two: those who reflected on the Critique of Pure Reason, [...] and those who lived on the Critique of Practical Reason," and that "an abyss separated them."14 Excepting the isolated objections directed at Kantian morality in the first chapter of the Two Sources, Bergson belongs, rather, to those who meditated deeply on the first Critique, and it will be seen that he respects its major divisions, that his work follows in its footprints in order to reform it from within, and to penetrate it sufficiently to make room in it for a path that would be able to introduce us anew to metaphysics. Bergson's Kantianism will certainly end up betraying the spirit of Kant, but what he means to sublate (aufheben) [relever] - in the double meaning of to overcome and to complete - through its revitalization in intuition, is no more and no less than Kantian metaphysics, the conditions of the possibility of which Kant had teased out before asserting its impossibility. We should not then be surprised that Bergsonian metaphysics will become an intuitive recovery [reprise] of the metaphysics that Kant - who lacked an experience capable of supporting it - had abandoned to the empty illusions of pure reason. By refusing, in his turn, the ancient metaphysics that he praises Kant for having leveled, Bergson means to revive, on a Kantian basis, "the metaphysics of the moderns," 15 such as it had already found its source in Descartes, and thereby to advance a metaphysics at least as modern as the critique that Kant had made of it - a critique, which some had thought could be substituted for metaphysics, once and for all.

\section{Integral Experience}

The opening pages of the "Introduction to Metaphysics" are celebrated, and yet what misunderstandings they have provoked! These misunderstandings arise from a definition of metaphysics, ascribed to Bergson, which he himself attributed to everyone and was unable to take up as his own without first submitting it to revision: "philosophers agree"16 to distinguish two profoundly different ways of knowing-through analysis and through intuition. The one revolves around the thing and grasps a multiplicity of 
viewpoint on it; the other enters into the thing and knows it absolutely. We understand that if Bergson is hesitant to use the word intuition, which "leads to a certain confusion," 17 this is because every metaphysics claims this term, and in adopting it for himself, he threw the ancient metaphysics that he rejected and the new metaphysics that he advanced into confusion. But it must have been for this very reason that he was compelled to use it, for he felt capable of fulfilling the ambitions that metaphysics had vainly boasted before him. In these pages he also had to present metaphysics in a state of indistinction, so that he would be able to subsume the metaphysics against which he fought and even to agree with those who objected, after Kant, that metaphysics alone was possible. In short, adopting the term intuition amounted to agreeing to enter into discussion with the metaphysics of the past and to revive [relever] its concerns against those who critiqued it. And of all of them, Kant was certainly the one who most clearly linked the success of metaphysics to the reality of an intuition: "One of the most profound and important ideas in the Critique of Pure Reason is this: if metaphysics is possible, it is through a vision and not through a dialectic. [...] He definitively established that, if metaphysics is possible, it can be so only through an effort of intuition." 18 From its incipit, the "Introduction to Metaphysics" takes over the definition that Kant-far from rejecting it in the framework of his transcendental dialectic-had himself formulated, before marking it as invalid for a reasonable and finite being. And further proof, were it even needed, resides in the first edition of 1903, where Bergson still designates intuition as "intellectual," retaining with this appended epithet the clear sign of its Kantian provenance. The article is therefore shot through with a profound equivocity, for it retains the sense of intuition sanctioned by Kant, before which the ancients fell and beyond which Bergson alone is resolved, after some reworking, to go.

For there are really two ways of understanding intuition, as there are of understanding integral experience. And it is necessary to begin with the ancient way. Following the latter, intuition would be able to attain the essence of the thing outside of its sensible unfolding; experience "would be given to me all at once in its entirety [intégralité],"19 whereas analysis, cut off from the essence, would only be able to gather fragments that are unrolled and scattered in space and time. Considered from this perspective, metaphysics claims to possess absolutely in eternity what science, which already moves in the relative, only studies as it is unfolded in exteriority. In such an arrangement, intuition clearly plays against analysis; and it can only lose. In this respect, Bertrand Russell and Moritz Schlick had an easy time promoting the discredited analysis against Bergson; they mistook their adversary and adopted a conception of analysis that was only the counterpart of intuition taken in its ancient meaning. Analytic philosophy contented itself with reversing the priorities and opposed to integral experience an experience that would be limited to the ensemble of fixed, distinct, and clearly identifiable objects. 
Kant was also right to discredit an intuition of that sort, which results from a divine archetype. For the metaphysics that aspired to it raised itself too high; it began with the "immediate search for the eternal" and returned with an empty and formal concept, which it said served in its place. It was also only dishonestly intuitive, being in fact intellectual: "[a]n intuition, which claims to project itself with one bound into the eternal, limits itself to the intellectual." 20 In other words, metaphysics has at times been able to call intuition suprasensible, but for want of ever really arriving at the suprasensible, it sought "to get this intuition from its very negation, analysis." 21 Is it a question of the soul? It is probably because the true intuition of the self, frail and fleeting as it is, in no way resembles what we hoped for that we have always preferred concepts that seem more solid - which is to say, at bottom, closer to intuition such as we imagined it to be. The perspective on the thing became the thing itself, and by a strange twist of fate, the Platonic idea became the paragon of the intuitive. Such is the eternal idea of Socrates that Plotinus makes accessible to nous and that his soul, whisked away by becoming, never stops converting into sensible reflections. As a result, "it is because of a confusion between the roles of analysis and intuition that the dissensions between schools of thought and the conflicts between systems will arise." 22 One must therefore applaud Kant, who, in refusing this conception of intuition, reduced metaphysics to what it truly was, namely, a simple combination of concepts, a "game of ideas," 23 which would have forever divided philosophers.

But Kant, in his turn, still granted too much to ancient metaphysics; he constructed his system of phenomena around an absent, secretly presupposed intuition and had to violate the negative conception of the noumenon he had wanted to create. Indeed, even though the "thing in itself" is not the ancients' essence, it occupies the place of the Absent and shares with it at least the requirement of being a real unity - that which sufficiently demonstrates the fact that analysis necessarily revolves around the thing. By refusing to enter into the thing, Kant was able to declare it unknowable; however, he still assumed it to be one, since the data of sensibility immediately splintered into a phenomenal diversity, which, insofar as it was not unified in and through the thing itself, had to receive the synthesis it lacked from the transcendental subject. A course taught on the Critique of Pure Reason at the Lycée Henri-IV in 1893-1894 fully confirms this: "Kant does not create a merely negative idea of the thing in itself. He represents it as a unity, but as a unity that is different than that of our thought-a unity that is not simply formal, a unity that consists in the presence and preexistence of the whole in relation to its parts, a unity comparable to that of life, and whose nature furnishes us with an image in what is called finality. Without this hypothesis, it seems, there is no speculative reason to believe in a thing in itself and not to establish the data of sensible intuition as absolute." 24 In other words, if the impossible were to occur and I were to reach my soul such as it is "in itself," I would at once grasp the living unity of my personality, from which stems the multiplicity of its 
phenomenal manifestations. Such a free and a-temporal act cannot, however, be grasped intuitively and, in Kant, will have to form the object of a postulate of pure reason. Kant thereby retains the ancient framework that he denounces, remaining close to Plotinus on certain points, as Bergson often suggests. 25

This confirms, as we have shown elsewhere, that the "Introduction to Metaphysics" is a tacit critique of the idea of synthesis - and not of analysis, which Bergson seeks, rather, to free and to revitalize in intuition. As long as it revolves around the thing, intelligence exercises a work of division; but let it be severed from the intuition that gives it its interior ballast and it changes in nature. Analysis turns into mere decomposition, which transforms the analyzed elements into fragments to be recomposed, and requires the annexation of an artificial unity from without that it can only superimpose upon them. This is what happened to Kant when he prohibited access to the thing itself. Having always already lost the original unity, sensibility had to start with a multiplicity of given sensations, "which derive, we know not how, from the things in themselves, and which insert themselves into time and space, pure forms of sensibility." 26 And the entire work of the understanding could only be a subsequent work of synthesis, which would consist in making the primitive unity of apperception descend into the "sensible diversity" so as to embrace it-spreading "over it the network of pure concepts, of schemas, of principles, which are so many formulas" 27 expressing the impersonal unity of the "I think." It could only give chaos a form by pouring it "into pre-existing moulds." 28 In short, for Kant, metaphysics would be possible if our knowledge went from the one to the multiple - it would go from intuition to analysis; but it turns out that it always goes from the multiple to the one-and from analysis to synthesis, for "from intuition one can pass on to analysis, but not from analysis to intuition." 29

There must then be another way of understanding intuition - namely, that of Bergson-which permits the fulfillment of metaphysics, while prohibiting the return to the metaphysics of the ancients. This is because Bergson did not so much reproach the ancients for going as far as they did, as for having placed their ideal so high that they could only reach it through empty concepts - transcendental ideas. Kant's only mistake, then, was in depriving himself of intuition by positing the absolute as a distinct [séparé] term, just as his adversaries had done, without realizing that the absolute is, on the contrary, "very near us and, in a certain measure, in us," 30 and that, for that very reason, intuition does not require us to "transport ourselves outside the domain of the senses and of consciousness." 31 Of course, for him to have this realization, it would have been necessary for him to have had the humble experience of pure duration, into which consciousness is immediately plunged and where it is already assured of reaching an absolute. For it is in this contact that Bergson was able to reform the meaning of intuition. Kant had discovered that in intuition unity is not external to the multiple, but 
internal to it by virtue of a multiplicity of fusion or interpenetration. Synthesis is immanent to it, so to speak, given immediately, before reflection refracts it in space and analyzes it into a multiplicity of disjointed instants. It is in thus bringing the phenomenon and the thing in itself closer together, and making analysis join up with intuition, if only by a thread, that a new meaning breathes life into both analysis and intuition, and allows Bergson to rework considerably what must be understood by experience, since it is thereby enlarged to the point of incorporating [intégrer] the thing itself. Note, on the contrary, how analysis, which Bergson makes revolve around the thing, only ever moves in space, leaving only duration to be, against Kant, the object of an intuition. Integral experience is no longer intuition, no more than it is analysis, but that which, in combining their jurisdictions, will only know a thing after having observed it from without and experienced it from within.

Accepting the simplification that Bergson allows himself in his abovecited course on Kant, we can say that "the Transcendental Analytic, on the one hand, and the Transcendental Dialectic, on the other, will demonstrate the legitimacy of physics, on the one hand, and the illegitimacy of metaphysics, on the other," 32 and that Kant has thereby cut experience in half, whether Bergson agrees to say with him that physics is true on the condition that it is not real (Matter and Memory), or whether he instead thinks that it only valid when it refuses to be extended to the totality of the real (Creative Evolution). Thus, the method of infinitesimal calculus gives a sufficient idea of what must be understood by Bergsonian metaphysics, ${ }^{33}$ since in defining it as "integral experience," 34 Bergson proposes to transcend the objective experience that Kant had grounded in the Transcendental Analytic, to the point even of penetrating the thing in itself, and of including [intégrer] the real itself, which the Transcendental Dialectic had firmly locked away. It is therefore no longer a question of the mind [l'esprit] attaining intuition without the help of analysis, but of dilating the former by means of the latter, operating "differentiations and qualitative integrations." 35 The intuition of duration is obstructed by analysis; it is less beyond than beneath. Bergson must critique the data that intelligence presents him with if he wants to go beyond the human condition and "seek experience at its source," where it is properly metaphysical. In reconstituting the form of the curve "with the infinitely small elements which we thus perceive of the real curve," "[t]he final effort of philosophical research is a true work of integration." 36

In thus sketching the two paths between which the Critique is, in his eyes, divided, Bergson's attitude toward Kant, which was always ambivalent, becomes clearer. Matter and Memory stigmatizes both "Kantian idealism,"37 which affirmed the relativity of our knowledge, and "Kantian realism," 38 which declared the "thing in itself" to be unknowable, forcing Kant to oscillate between two movements, pursuing neither to its final consequences. It is not, however, until the final chapter of Creative Evolution that Bergson thematizes this double tendency inherent in Kant's philosophy. On the one hand, he 
writes, "it is only a continuation of the metaphysics of the moderns and a transposition of the ancient metaphysics." 39 Here, Bergson returns to the critique that he had addressed to him in the "Introduction to Metaphysics": Kantianism is only a Platonism in which the ideas, illegitimate if they are things (metaphysics), become legitimate if they descend to earth in order to be relations (science). Such that "the whole Critique of Pure Reason rests also upon the postulate that our thought is incapable of anything but Platonizing." 40 In Kant as in Plato, the real ends up being resolved into intelligible terms. But on the other hand, in reducing the hypotheses needed by mechanical science to the minimum, Kant does not go as far as Spinoza or Leibniz, and restrains his metaphysical expansion by stopping short before the thing in itself. He thereby "stops this dogmatism on the incline that was making it slip too far toward the Greek metaphysics." 41 And it is at this point that Bergson discovers the germ of a second philosophy. For Kant's recoil allows him to grant Galilean physics an indefinite extension while wagering on his metaphysical abdication. In concerning himself only with phenomena, Kant liberates new, unknown lands that unlock the thing in itself and immediately shut it away again, pointing the way while barring our entrance, for want of the ability to penetrate it with an "intellectual intuition":

Thereby he prepared the way for a new philosophy, which might have established itself in the extra-intellectual matter of knowledge by a higher effort of intuition. Coinciding with this matter, adopting the same rhythm and the same movement, might not consciousness, by two efforts of opposite direction, raising itself and lowering itself by turns, become able to grasp from within, and no longer perceive only from without, the two forms of reality, body and mind? ${ }^{42}$

In other words, the metaphysical withdrawal of physics liberated, with the thing in itself, a matter rendered inalienable by intelligence, but Kant, having raised it too high, prevented himself from accessing it otherwise, resigning himself to his incapacity to reach it. He thereby prepared a new way, or rather summoned anew "that essential element of the philosophy of Descartes which had been abandoned by the Cartesians." 43 But instead of reviving Cartesian intuitions, he preferred to expel them outside of the self, into the "thing in itself" - rather than accepting their immediate givenness [donation], as Descartes before him had agreed to do: the feeling of freedom, the union of the soul and the body, etc. He could have gone a step farther than Descartes; instead, he took a step back. Freedom was banished, raised "to the sphere of noumena," 44 and the union of sensibility and understanding became "a hidden art in the depths of the human soul." 45 But even though Kant, lacking a true intuitive experience, was only able to re-establish their truth on the moral plane, this was, at the very least, something more than the elimination of even their possibility, the pure and simple denial that there is time, that there is freedom, that there is union - as was the case for the Cartesians, with Spinoza and Leibniz in the lead. It was the demarcation of the empty place 
that metaphysics would once again be able to occupy, the empty place for "a revivified Cartesianism." 46 In beginning with the conquest of these new territories, Bergson gives himself the intuition that Kant refused. In plunging back into pure duration, he makes explicit his project of gradually integrating into experience those portions of the real to which Kant had failed to gain access.

\section{The Reprise of the Tripartite Structure of the Critique}

What can it mean for Bergson to pursue in this way the path that Kant had indicated? As he reflects on his renewed metaphysics, Bergson seems to want to rework the tripartite structure of the Critique (Aesthetic / Analytic / Dialectic) such that it would be able to accommodate the intuition that Kant had condemned. Even though the formulation is as hasty as it is exaggerated, we could say that Bergson is a Kant who had previously discovered the intuition of duration, and who rewrote the Critique of Pure Reason under the influence of his discovery. Far from constructing his philosophy against Kant, in "a decided and decisive opposition with respect to Kant," 47 as has often been maintained after Madeleine Barthélemy-Madaule, Bergson finds in him, on the contrary, a powerful ally for penetrating farther into the metaphysical deepening of intuitive reality, into which Descartes had already begun to enter. The Cartesian intuitions - weak, marginal, and soon rejected by the Cartesians themselves - will find in the Critique of Pure Reason one of the instruments for their intensification. Kant had taken a step backward with respect to Descartes' advances. Nevertheless, Bergson's Kantianism will take a step forward and will be-in his own words, which must be taken à la lettre-a "revivified Cartesianism." Bergson is the philosopher who truly wanted to introduce "Descartes into Kant," pouring a Cartesian matter into a Kantian form. Proposing to redeploy modern metaphysics by passing through the sieve of the Critique, Bergson must revisit the Critique and invest it from within; for he is aware of the fact that there he will be able to fan the flames of intuition, instead of leaving its embers to dwindle and die.

\section{Transcendental Aesthetic}

It is necessary to begin with the Aesthetic, since it is also there that Bergson begins his own reading of the Critique in Time and Free Will. In his eyes, Kant had the virtue of making time and space "intuitions, and not concepts," 48 by distinguishing sensibility and understanding at precisely the point where they had been confused before him. His mistake is having thought that it was necessary to demonstrate their transcendental ideality in order to be able to grant them an empirical reality. The formal intuition of space can itself be the object of a real experience, which is why, in place of the transcendental deduction, Bergson will propose, in Creative Evolution, a real genesis of 
spatiality and intelligence, each engendering the other. There, he will add to the Kantian thesis an "intelligence earned by intuition," 49 which allows him to ground intellectual knowledge in reality itself, reserving for physics the ability to reach half of the absolute. But that should probably not be considered a critique of Kant, being rather a readjustment of the doctrine once it has been brought up to speed with evolutionism. Bergson can also grant to Kant, in Time and Free Will, that space is an "a priori form of sensibility," 50 and then go on to say, in Creative Evolution, that "[w]hat the Transcendental Aesthetic of Kant appears to have established once and for all is that extension is not a material attribute of the same kind as others."51 For in having "admitted that homogeneous space is a 'form of our sensibility'," 52 Bergson is better able to argue with him about time-in relation to which the real is rediscovered, heterogeneous and continuous matter. Such is the subtle point upon which Bergson's critique focuses: Kant missed the experience of duration due to the unwarranted parallel that he established between time and space, confusing "true duration with its symbol." 53

The point is subtle-a spatialized time-but from the perspective of a Kantianism of Bergson, this objection is not what closes the dialogue with Kant, but is its opening. If Bergson had wanted to reject Kantian critique in its entirety, he would not have focused his attack on a point as limited as that of the notion of time in the Transcendental Aesthetic. Besides, was it really a critique? Bergson also recognizes that he would not have been able to wrest the experience of duration from the space that is ordinarily imposed upon it if Kant had not begun by distinguishing between the matter and the form of knowledge. And how can one achieve such a distinction, and make it "very precise," without first overdoing it a little, without beginning with the assimilation of time to space, making it a form like space? Without this initial excess, Bergson writes, "this vital distinction would probably never have been made." 54 But once made, time always comes to rein it in; once made, Bergson could always nuance this "overly sharp" distinction and reintroduce time into the very matter of our knowledge.

This is because, for Bergson, it is not a matter of making a system collapse by removing one of its stones, but, on the contrary, of seeping into the system after having hollowed out a breach, and thus of saturating Kantianism by making the intuition he discovered flow through it. The Kantian system was impervious to the real. With the experience of duration, as Péguy writes, Bergson finds "the almost initial, particularly well placed, particularly well found node of resistance, and of weakness, like the chink in the armor, if not of all Kantianism, at least of all critical Kantianism." 55 And, thanks to this chink in its armor, Kantianism, invincible up to that point, is going to know the wound of the real, which it can no longer declare to be beyond reach as the "thing in itself." In view of the books to come, Bergson neither rejects Kantianism nor seeks to demolish it, but finds in this point of the Transcendental Aesthetic the Achilles heel of this other "battleship of the 
Dreadnought class," 56 the flaw through which the real, in establishing one fact and one fact only-undeniable experience-will be able to penetrate the system anew and irrigate it with its vitality.

Bergson's Kantianism will therefore differ profoundly from that of Kant's immediate successors, especially Schopenhauer, Fichte, and Schelling. They all wanted to dominate the Kantian Everest by attacking it directly, at its summit-the Transcendental Dialectic. They all granted themselves the intellectual intuition that Kant had declared to be beyond the essentially finite, essentially sensible human condition. Repeating the error of the ancients with even more clarity, they removed themselves from time and space in order to "project [themselves] with one bound into the eternal," 57 and fell back upon an empty concept - the "Will," the "Ego," or even the "Absolute" - in lieu of intuition. Bergson, on the contrary, enters into the Critique along winding paths, which are longer and harder going, yet are more certain, in the end, of reaching the summit. For, in order to win (supra)intellectual intuition, he only needs sensible intuition in the beginning, convinced that the latter is found to be "in continuity with it through certain intermediaries." 58 The error of the Kantians was having followed Kant in the overly sharp separation that he made between them, without perceiving that there is no other way to surpass human experience than to sink down into it by installing oneself in sensible intuition, which already reaches the absolute and promises to intensify in metaphysical intuition. And Bergson can only pass from the one to the other through the detour of the critique of our habitual instrument of knowledge, which he sometimes calls by its Kantian name, "understanding," and which cannot be surpassed unless we know its limits. Inserted between the Aesthetic and the Dialectic there must then be the Analytic, which he will have to master if he is to be fortified by the concepts intelligence provides us with, and from which the frail light of our evanescent intuitions is able to reflect back to us, filtered and intensified.

\section{Transcendental Analytic}

Bergson also basically preserves the Transcendental Analytic in its place, making a series of adjustments to it, all destined to irrigate the canals of the "Critical" system with the intuitive experience of pure duration, which is its new source and initial breakthrough. We will examine two major adjustments.

(i) As we have seen, Bergson praised Kant for having been economical with respect to Spinoza and Leibniz, since he grounded Galilean physics on a minimum of hypotheses, thereby managing not to slide too far down the slope of Greek metaphysics. In withdrawing time from the ranks of the required hypotheses, Bergson can be more economical still on such a path, for he grounds the objective validity of mechanical science exclusively on the spatiality inherent in things. Consequently, the table of categories is no longer 
necessary, including the category of causality, from which even Schopenhauer had still not strayed. It is not even necessary to consider a priori synthetic judgments. For those are all exercised in a time that science essentially seeks to eliminate, even though it sometimes remains ignorant of the fact that it tends toward the principle of identity as toward its goal. In those cases "where the probability is so high that it is tantamount to certitude, in arithmetic, for example," 59 Kant would have been able to concede, at least approximately, that mathematical propositions can be assimilated to analytic judgments, instead of defining them as a priori synthetic judgments. At bottom, the principle of identity is sufficient and the frames of intelligence are absorbed back into it. In short, the notion of space upon which mathematics itself is grounded, remains a sufficiently solid base upon which Galilean physics can stand. And if Bergson makes it successively into an "a priori form of the sensibility," then into a "diagram [schème],"60 finally a "schema [schèma]" 61 that intelligence has at its disposal, this is because his concern is to shift from the Aesthetic toward the Analytic, so as to make the weight of the constitution of objectivity weigh on the latter, and to give sensible intuition back its immediate access to the things themselves. But in another sense, this shift, being only a consequence of the discovery of pure duration, retains what is essential in the Kantian achievement, which limits the mechanism of science and clearly demarcates a place for metaphysics. The Kantian distinction between the thing in itself and the phenomenon is much too sharp for Bergson to accept it as such, and it is quickly replaced by the distinction between the whole and the part. But not, as we have already said, before bestowing certain benefits. Indeed, without it, "the principle of causality and, consequently, nature's mechanism [would] necessarily be valid for every thing in general." 62 "[S]ince the principles of knowledge are uniquely destined to organize experience and converge with mechanism," without the existence of the thing in itself, "mechanism [would] overrun everything." 63 In short, for Kant, physics only gains its validity to the extent that it loses the thing in itself (as Matter and Memory will put it) or at least abandons half of reality (as Creative Evolution will correct). In other words, the truth of the sciences rests upon a tacit contract that forbids them to encroach upon the things themselves and to apply the principles of knowledge to that which resists them and gives birth to the transcendental illusions of pure reason. Everything, then, is reversed; it is not Bergson who can be accused of being pre-critical, but his most fierce adversary: materialism. What a return to sender! It is really the theses of materialism, or those of contemporary monism, that, as he again says in his course, "are found to be lagging behind the Kantian critique." They overflow into the transcendental dialectic and claim to cover reality in itself with the very conceptual blanket that the Critique of Pure Reason had successfully contained in making it available for a different experience. Let us add that the distinction Bergson repeatedly makes between mechanism as "method," which must be praised, and mechanism as "doctrine," 64 which must be criticized, is also owed to Kant. Kant showed in his dialectic that there is 
certainly a speculative interest in presuming the determinism of phenomena to be extensible to infinity, namely, that it "encourages and furthers knowledge," 65 but on the strict condition that this not be posited in a manner as dogmatic as the dogmatism to which it is opposed.

(ii) The second and principal adjustment that Bergson makes at the heart of the Transcendental Analytic is that of grounding the unity of mechanism on action, and no longer on thought alone, which is to say, on the synthetic unity of apperception - "The I think must be able to accompany all my representations." 66 Such is the theory of knowledge that Bergson sketches starting with Matter and Memory, which allows him return to the instrument of our knowledge, highlighting its limitation and no longer its relativity. For, with the pragmatic turn he gives to it, Bergson will know how to surpass intelligence in the direction of a positive metaphysics, the a priori revealing itself to be nothing but habit. But, once again, what is essential in the Kantian achievement is retained. In order to be surpassed, the limits must remain secured, as Kant, before him, had secured them in the Transcendental Analytic. Whether they are principles of knowledge or frames for our action changes nothing of the matter: by abandoning experience in order to function in a purely speculative manner, they lead, just the same, to the creation of "insoluble difficulties," which stem from "the self-contradiction into which the intellect can fall when it speculates upon things as a whole."67 The introduction to the seventh edition of Matter and Memory concludes on a Kantian note: "[...] the habits formed in action find their way up to the sphere of speculation, where they create fictitious problems, and [...] metaphysics must begin by dispersing this artificial obscurity." 68 Bergson and Kant both denounce the same transgressive gesture: intelligence creates antinomies as soon as it leaves the ground of the experience to which it is practically destined - matter.

These two adjustments have the effect of reconciling science and metaphysics right where Kant established their separation. For, in making their spheres meet, Bergson restores the honor of experience in two respects: first by leading metaphysics back to the facts (Analytic), and then, thanks to intuition, by giving experience an extension that it did not have in Kant, impinging upon the domain of metaphysics (Dialectic). In other words, on the one hand, Bergson transports metaphysical problems onto the field of observation, so that they will cease to "forever [give] rise to fresh disputes of the schools within the closed lists of pure dialectic." 69 And on the other hand, because he has already shown in Time and Free Will that an intuitive experience overflows the frames that give it its form, metaphysics will no longer be declared to be that which gives rise to antinomies, but, on the contrary, that which resolves them. Accompanied by this twofold demand, the transcendental dialectic, which traced the perimeter of an impossible metaphysics, will, in Bergson, be able to develop gradually into a concrete metaphysics. Such that by beginning with "the very premises that Kant 
posited," Bergson can assert, in one of his still unpublished courses, that he is able to draw from them "a completely, absolutely different conclusion," 70 and through a fortuitous reversal, revitalize metaphysics at the precise place where Kant had left it for dead.

\section{Transcendental Dialectic}

In closing, it is the Transcendental Dialectic that Bergson takes over in its entirety, that he even rigorously maintains as the ever-valid critique of metaphysics. It is necessary to guard against a hasty reading that would say, on the contrary, that this is one of the achievements to which Bergson does not return: Kant's Critique "is, in my opinion, definitive in what it denies."71 Armed only with physical principles, reason was bound to take itself for its own worst enemy and to transform metaphysics into a field of battle. It is therefore an immense achievement to have prohibited it from pronouncing itself for or against the existence of the soul, of the world, or of God, by invalidating the specious arguments through which it contradicts itself. And Bergson can be grateful to him for having cleared away the ancient metaphysics, which, as it held sway from Plato to Leibniz and beyond, advanced through the combination of concepts, and which was the only metaphysics that Kant knew. For this reason, Bergson employs the term "dialectic," even "pure dialectic," in an intentionally Kantian sense, though he brings it surprisingly close to its Platonic meaning. ${ }^{72}$ Kant thus preserved an entire domain, driving intelligence away from it in order to prevent it from being further laid to waste. But where he holds himself back from engaging, from "installing himself" "through a superior effort of intuition," withdrawing, in his turn, like a wave following its reflux, Bergson decides to press on with his reconciling intuition. Because he is armed with duration, he can reverse the meaning of the Kantian Critique: as soon as experience allows itself in fact to transgress the Kantian prohibition, intelligence ceases to be "relative," revealing itself instead to be "limited"73 to the practical frames in which it confined experience. As soon as the limit is crossed and experience is discovered beyond its frontiers, it no longer seems as though metaphysics transgresses experience; it seems, on the contrary, that it must transgress the understanding if wants to define itself as "integral experience." Ancient metaphysics worked with empty concepts in an infinite dialectic that put intelligence in contact with itself; the new metaphysics rests upon an intuition that allows it to make intelligence overflow in the direction of a properly metaphysical experience, larger than the conditions of possibility that direct its performance [la mettent en scène] by submitting it to objectivity. This is because intelligence does not cover experience perfectly. But whereas Kant, on the basis of an imperious way of thinking, asserted the latter to be narrower than the former, Bergson discovered it to be the wider of the two. For it is enough for intuition to succeed in penetrating the thing itself, as it does in Bergson, for it to escape from the concept's sights, overflowing it in all 
directions. Allowing ourselves to plagiarize in advance, we could say that, in Bergson, the phenomenon is saturated with intuition to the point of exceeding every concept and of subverting even the principles of knowledge. ${ }^{74}$ And because Bergsonian metaphysics is, as Bergson himself said, "completely saturated with experience," 75 transcending physics amounts to "transcend[ing] pure intelligence," 76 to joining up with bare experience, not leaving it behind.

Making Bergson's Kantianism explicit, as we have just done, gives us the opportunity to give Bergsonian metaphysics a precise status and, at the same time, to make sense of a passage in the Introduction to The Creative Mind that still seemed obscure to us. In it, Bergson states that science embraces part of reality and is therefore "already fulfilling half of the program of the old metaphysics,"77 and that the other half must be returned to metaphysics, properly speaking. The Wolffian distinction between metaphysica generalis and metaphysica specialis is certainly taken up again, here, but to the exact extent that it maps precisely onto the contours it was given in the Critique of Pure Reason. The physical science that is grounded in the transcendental analytic reaches the absolute and could rediscover, with Bergson, its ancient name of general metaphysics "if it did not prefer to keep the name of science."78 For following Kant's replacement of "the proud name of an ontology" with "the modest one of a mere analytic of the pure understanding,"79 Bergson concludes by granting such an analytic the ability to reach one of the two parts of the absolute, and granting science the ability to fulfill one of the two halves of the program of ancient metaphysics-namely, metaphysica generalis: knowledge of matter. On the other hand, the metaphysics that is invalidated by the transcendental dialectic must be capable of relating to the other half of the absolute: knowledge of mind [l'esprit]. After Gilles Deleuze and Alain de Lattre, anyone who wants to see a Bergsonian ontology will have to explain, among other things, this Bergsonian declaration, which, in my opinion, definitively buries the very possibility of any such ontology. Deleuze will formulate an "ontology of duration," through which Bergson, in creating his own problems, will have sought to free himself from the ancient problems, once thought to be eternal: those of the soul, the world, and God. It is necessary to recognize, however, that the opposite is in fact the case. Not only is there no and can there be no ontology in Bergson (as the theory of knowledge requires), but if there is a metaphysics, it is the very same metaphysics that Deleuze had refused to find in Bergson, and which bears upon the soul, the world, and God: namely, metaphysica specialis. Finally, let us add that if he follows the Critique of Pure Reason, Bergson is able to give a different designation to the tripartition that governs it, which would overlap, in a certain sense, with the tripartition that Frédéric Worms located in Bergson's own work, especially in Matter and Memory: ${ }^{80}$ psychology, theory of knowledge, and metaphysics - with this difference, that by psychology, it will be necessary here to understand reality such as it is given to immediate 
consciousness, and not the discipline that takes the latter as the theme of its study.

Kant will have been less the Christopher Columbus of a new world than its Moses, dying before setting foot in it and stopping at its borders, already too old to believe it possible to cross them, but raising his finger toward this terra incognita, calling on new generations who will have the courage to venture forth and to live through still untried experiences. It was enough for Bergson to have discovered pure duration in the hollow of an intuition to reverse the meaning [sens] of the Kantian Critique: the domain of special metaphysics, which the transcendental dialectic had closed off, is freed once more, but not without having benefitted from the groundwork carried out by the critical effort. Indeed, if Kant made it definitively possible to reject dogmatic metaphysics, it is quite likely that the intuitive recommencement [relève] that Bergson enacts will not make the new metaphysics fall back upon the failings of ancient metaphysics and will not identify itself with any of the positions that have already been occupied and that Kant has condemned in advance in the framework of his pure dialectic. One must, then, go farther and another contribution will be necessary if one wants to show how Bergson's œuvre follows the program of special metaphysics step by step, going back over the very ground that Kant had covered, following his footprints, following the rhythm of the transcendental ideas of pure reason in the exact order he had given them in the Transcendental Dialectic. Should this interpretation prove correct, we would also be in a position to perceive, on the basis of their respective readings of Kant, the widely diverging interests motivating the decision, in Heidegger and in Bergson, to introduce us to metaphysics anew: an ontological re-reading of the Transcendental Analytic in the Kantbuch ${ }^{81}$ and an empirical re-reading of the Transcendental Dialectic in the works of Bergson. There, Kant had presented a magnificent program and Bergson, with intuition as his figurehead, wanted to take hold of its promises, declared by Kant to be untenable. Let us content ourselves here with drawing up a chart of this program, in the hopes of returning to it later in greater detail:

\section{Time and Free Will}

I. Rational psychology: the paralogisms of pure reason
i. Paralogism of substance
ii. Paralogism of simplicity
iii. Paralogism of personality

According to Kant, these three concepts give us "spirituality." 82

\section{Matter and Memory}

i. Paralogism of the ideality (of outer relation) 
Its status differs from the first three paralogisms in that it relates the soul "to objects in space" and bears upon "the commerce with the body."

II. Rational Cosmology: the antinomies of pure reason

i. First antinomy of pure reason

ii. Second antinomy of pure reason

Creative Evolution

iii. Third antinomy of pure reason

iv. Fourth antinomy of pure reason

The Two Sources of Morality and Religion

i. Rational theology: the Ideal of pure reason 
1 Henri Bergson, "Introduction I," in The Creative Mind [hereafter, CM], trans. Mabelle L. Andison (New York: Citadel Press, 2002), 28 [translation modified].

2 Henri Bergson, "Introduction to Metaphysics," in CM, 159. [TN: The reference is to a footnote that was left out of the English translation.] Cf. also "Introduction II," in CM, 70-71.

${ }^{3}$ Bergson, "Introduction II," 64.

${ }^{4}$ Bergson, “Introduction I," 29.

${ }^{5}$ Bergson, "Introduction II," 65.

${ }^{6}$ Henri Bergson, "Life and Consciousness," in Mind-Energy, trans. H. Wildon Carr (New York: Henry Holt and Company, 1920), 4.

7 Indeed, who remembers that they are present in the first edition of 1781? "On this transcendental illusion of our psychological concepts, then, three dialectical questions are grounded, which constitute the proper goal of rational psychology, and cannot be decided otherwise than by the above investigations. These questions are, namely: 1) about the possibility of the community of the soul with an organic body, i.e., the animality and the state of the soul in the life of the human being; 2 ) about the beginning of this community, i.e., of the soul in and before the birth of the human being; and 3 ) as to the end of this community, i.e., of the soul in and after the death of the human being (the question concerning immortality)." Immanuel Kant, Critique of Pure Reason [hereafter, CPR], trans. and ed. Paul Guyer and Allen W. Wood (New York: Cambridge University Press, 1998), A384, 433.

${ }^{8}$ Bergson, "Life and Consciousness," 5.

${ }^{9}$ Bergson, "Introduction II," 65.

${ }^{10}$ Madeleine Barthélemy-Madaule, Bergson adversaire de Kant (Paris: PUF, 1966).

${ }^{11}$ Henri Bergson, "Philosophical Intuition," in CM, 113.

12 Alain Panero, "Kant, précurseur manqué de Bergson," Revue philosophique de la France et de l'étranger, no. spécial "Bergson” (Paris: PUF, 2008).

${ }^{13}$ Bergson, "Introduction I," 28 [translation modified].

${ }^{14}$ Charles Péguy, Heureux les systématiques, posthumous (1905), in CEuvres en proses complètes, II (Paris: Gallimard, "Bibliothèque de la Pléiade," 1988), 288.

${ }^{15}$ Bergson, “Introduction to Metaphysics," 198.

16 Ibid., 159.

17 Bergson, “Introduction II," 30.

${ }^{18}$ Henri Bergson, "The Perception of Change," in CM, 139-140.

${ }^{19}$ Bergson, “Introduction to Metaphysics," 160.

${ }^{20}$ Bergson, "Introduction II," 31.

${ }^{21}$ Bergson, "Introduction to Metaphysics," 172.

22 Ibid., 169.

${ }^{23}$ Ibid., 168. 
${ }^{24}$ Henri Bergson, "Leçons sur La Critique de la Raison pure," Lycée Henri-IV, 1893-1894, Cours, III, ed. H. Hude (Paris: PUF, “Épiméthée," 1995), 172.

${ }^{25}$ Cf. Bergson, "The Perception of Change," 139-141; Course at the Collège de France in 1906-1907 on "Les theories de la volonté," in Mélanges (Paris: PUF, 1972), 717; "Cours sur Plotin," École normale supérieure, probably 1898-1899, Cours, IV, ed. H. Hude (Paris, PUF, “Épiméthée," 2000), 47.

26 Bergson, "Leçons sur La Critique de la Raison pure," 167.

27 Ibid., 167.

${ }^{28}$ Bergson, "Introduction to Metaphysics," 197.

29 Ibid., 180.

30 Henri Bergson, Creative Evolution [hereafter, CE], trans. Arthur Mitchell (Mineola, NY: Dover Publications, 1998), 299.

${ }^{31}$ Bergson, "Philosophical Intuition," 127-128.

32 Bergson, “Leçons sur La Critique de la Raison pure," 167.

${ }^{33}$ Cf. Jean Milet, Bergson et le calcul infinitésimal (Paris: PUF, 1961); cf. David Lapoujade, Puissances du temps (Paris: Minuit, 2010), ch. 1.

${ }^{34}$ Bergson, "Introduction to Metaphysics," 200 [translation modified].

35 Ibid., 191.

${ }^{36}$ Henri Bergson, Matter and Memory [hereafter, MM], trans. N.M. Paul and W.S. Palmer (New York: Zone Books, 1991), 185.

37 Ibid., 227, 230.

38 Ibid., 230-231.

${ }^{39}$ Bergson, $C E, 356$.

${ }^{40}$ Bergson, "Introduction to Metaphysics," 197.

${ }^{41}$ Bergson, CE, 357.

42 Ibid., 358.

${ }^{43}$ Ibid., 358.

44 Henri Bergson, Time and Free Will [hereafter, TFW], trans. F.L. Pogson (Mineola, NY: Dover Publications, 2001), 232.

${ }^{45}$ Kant, CPR, A 141 / B 180, 273.

${ }^{46}$ Bergson, CE, 358.

${ }^{47}$ Alexis Philonenko, Bergson ou de la philosophie comme science rigoureuse (Paris: Cerf, 1994).

${ }^{48}$ Bergson, “Leçons sur La Critique de la Raison pure," 153.

49 Frédéric Worms, “L'Intelligence gagnée par l'intuition? La relation entre Bergson et Kant," Les Études philosophiques, no. 59 (2001/4), 453-463.

${ }^{50}$ Bergson, TFW, 94.

${ }^{51}$ Bergson, CE, 203-204. 


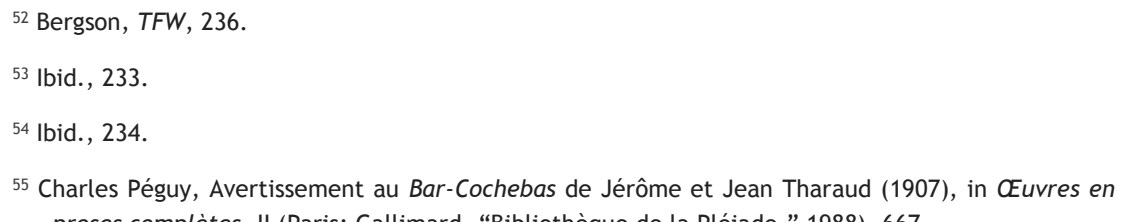
proses complètes, II (Paris: Gallimard, “Bibliothèque de la Pléiade,” 1988), 667.

56 Bergson, “Philosophical Intuition," 113.

57 Bergson, “Introduction II,” 31.

58 Bergson, CE, 360.

59 Bergson, “Leçons sur La Critique de la Raison pure,” 144.

${ }^{60}$ Bergson, MM, 206, 210-211, 219.

${ }^{61}$ Bergson, CE, 202.

62 Bergson, “Leçons sur La Critique de la Raison pure,” 135.

63 Ibid., 134.

${ }^{64}$ Bergson, CE, 346.

${ }^{65}$ Kant, CPR, A 472 / B 500, 501.

66 Ibid., B 131, 246.

${ }^{67}$ Bergson, “Introduction II,” 39.

68 Bergson, MM, 16.

69 Ibid., 16.

70 Cours au Collège de France sur “L'Idée de temps," séance du 11 avril 1902, Dactylogramme no. 1, p. 9, Bibliothèque du Fonds Doucet, which we thank for allowing us to reproduce this extract.

71 Bergson, CE, 205.

${ }^{72}$ Cf. Bergson, “Introduction II," 81, 90.

73 Bergson, CE, 358.

74 Jean-Luc Marion, Being Given: Toward a Phenomenology of Givenness, trans. Jeffrey L. Kosky (Stanford, CA: Stanford University Press, 2002), §21, "Sketch of the Saturated Phenomenon: The Horizon."

75 Bergson, “Le parallélisme psycho-physique et la métaphysique positive," followed by a discussion, in Mélanges, 501.

76 Bergson, CE, 199.

77 Bergson, “Introduction II," 43.

78 ibid. , 43.

${ }^{79}$ Kant, CPR, A 247 / B 303, 358-359.

${ }^{80}$ Cf. Frédéric Worms, Introduction à Matière et mémoire (Paris: PUF, “Les Grands Livres de la philosophie," 1997, $2^{\text {nd }}$ ed., 2008). 
${ }^{81}$ Martin Heidegger, Kant and the Problem of Metaphysics, $5^{\text {th }}$ ed., trans. Richard Taft (Bloomington and Indianapolis: Indiana University Press, 1997).

82 Kant, CPR, B 403, 414. 